\title{
Development of the landslide risk classification for natural and man-made slopes based on soil watering and deformation extent
}

\author{
Oleksandr Kovrov $^{1 * \otimes(\mathbb{D})}$, Valerii Kolesnyk ${ }^{1 \otimes(\mathbb{D})}$, Yurii Buchavyi ${ }^{1 \otimes(1)}$ \\ ${ }^{1}$ Dnipro University of Technology, Dnipro, 49005, Ukraine \\ *Corresponding author: e-mail kovralex1@gmail.com, tel. +380672817589
}

\begin{abstract}
Purpose. To summarize and formalize the estimates of landslide risk levels based on the proposed classification of relevant environmental or man-made risks in the regions of Ukraine and local territories, including a gully-ravine network and manmade slopes of technology-related objects that represent certain environmental or man-made risk for residential areas.

Methods. To achieve the objective, the following methodological approaches have been applied: analysis of the literature regarding state-of-the-art research on the issues of landslide phenomena assessment and prediction at regional and local levels, zonal-statistical analysis of orographic data for the each region of Ukraine with calculations of the relief integral coefficients, methods for comprehensive evaluation of natural and man-made slopes stability with the con-sideration of their geometry, water saturation, geoclimatic conditions and technogenic impacts; methods of geomechanical assessment, environmental evaluation and forecasting of landslide risk in natural geosystems and man-made slopes based on the stability factor, and scientific generalization of landslide risks using mathematical models developed by the authors and proposed criteria for watering extent and soil deformation in natural and man-made slopes.

Findings. The five-level scale for evaluating landslide risk for natural and man-made slopes has been substantiated in terms of their stability control. The proposed landslide risk scale makes it possible to forecast reliably the geomechanical state of the rock mass depending on the values of the slope stability factor in changing geoclimatic conditions and substantiate effective anti-landslide engineering measures. Landslide risk classification of natural slopes according to the stability factor value has been proposed. The scale is recommended for assessing the stability of man-made slopes comprised of solid and bulk rocks and for forecasting the environmental risk from landslides resulting from emergency situations
\end{abstract}

Originality. It has been proved that the number of landslides per unit of precipitation in a region with certain relief is a constant value. The dependences for determining the critical amount of precipitation that will cause a single landslide within the gully-ravine network depending on the specific area of the landslide- prone site and on the relief have been obtained.

Practical implications. The five-level classification scale of landslide risk for natural and technogenic slopes in respect to annual precipitations and relief coefficient has been substantiated. That helps forecast landslides and determine the level of environmental and technogenic risk inflicted therefrom.

Keywords: landslide, landslide risk, natural slopes, man-made slopes, classification of landslide risk levels

\section{Introduction}

Displacements of land surface in natural and man-made slopes are considered as the sources of potential environmental risks, including the man-made ones, which often result in emergencies or disasters. Taking into consideration the trends in global and regio-nal climate changes, landslides in terms of natural sloping landscapes and technogenic slopes (i.e. open pit benches or waste dumps of all kinds) as well as geotechnical structures, even urban dumps, and solid landfills are possible due to moisturing of the upper layers of unstable loamy and loess soils [1], [2].

The main natural factors of landslide activation include the amount and intensity of precipitations, terrain features, soil composition, external loads, seismic impacts etc. In this case, human activity is an additional factor in the development of a landslide process due to increasing soil moisture as a result of water supply or sewer failures, external loads on the earth's surface, undercutting of slopes during the construction operations, dynamic loads from transportation or blasting etc.

Therefore, adequate preliminary assessment of landslide levels across the regions in terms of gully-ravine network or man-made slopes will help increase the environmental and technogenic safety by the dependable forecast of landslides and their possible consequences; that will make it possible to implement an effective system of protective anti-landslide engineering measures. 
There is a wide range of current publications related to the landslide phenomena.

Study of the effects of both climate change and increasing atmospheric precipitation on the landslide intensification in Asia, South America, and Africa was carried out on the basis of numerical simulation and regressive analysis of the landslides, caused by climatic changes in the temperature and precipitation, and the probabilistic landslide risk models at the regional level [3]. As a result of global warming, the frequency and intensity of precipitation, being the main factor of rapid landslides, is constantly increasing. These consequences of global warming and the development of EGP are difficult to predict and evaluate.

The landslides occur in the form of flows and shears of soil as well as destruction of the surface geolayers and displacements. Landslides have the characteristics of the development and distribution for specific regions or even continents and play an important role in the evolution of landscapes. In many regions, they also pose a threat to local infrastructure and population [4].

Natural phenomena, including precipitation, snow melting, temperature changes, earthquakes, volcanic activity as well as anthropogenic activity, are the dominant factors of slope stability, if landslide occurs. The mechanisms by which a climate change can affect landslides and reduce stability of natural and engineering slopes are studied systematically through the evaluation of the impact of forecasted climatic changes on the landslide processes [5]. Therefore, it is expected that in the future, climatic changes will continue to affect slope stability in terms of different time and geographic ranges [6].

Similar results were obtained for mountainous areas in the north-east of Italy, where precipitation reduction and, accordingly, reduction of shear activity in spring periods took place. Studies in the south-east of England demonstrated that the recorded $11 \%$ increase in the average annual precipitation predominantly in winter as well as $13 \%$ increase in moisture evaporation due to the increased average annual temperature resulted in the changing soil moisture and its reduced deviations in slopes [3].

Geotechnical analysis for predicting the future behavior of active landslide processes in Basento valley (Southern Italy) using different climatic scenarios shows that, with the decrease in average daily precipitation by $2.4 \%$ and the increase in average daily temperature by $0.04 \%$ for every ten years for the period of 1965-2100 will reduce the level of groundwater by $8 \mathrm{~mm}$ and decrease the soil displacement by $77-86 \mathrm{~cm}$.

Thus, according to the analysis results, the expected changes in climate are not significant; however, that affects the dynamics of the landslide process due to the modest decrease in the amount of annual precipitation and temperature rise [7].

While studying the expected landslides within the area of Orvieto (Umbria, Central Italy), it was established that the decrease in precipitation would slow down the sloping processes [8]. The worst scenario for the development of Taiwanese mountainous terrain was estimated in the paper by Chang \& Chiang [9]; it was found that with the increasing amount of precipitation by $15 \%$ in the average annual maximum for the study periods of 1960-2008 and 2010-2099, the average intensity of the landslides would increase by $12 \%$.

The represented analysis of modern studies is just a brief description of rather complex dependence of the influence of various factors on the development of natural landslides that draws an interest to the reliable forecasts and methodology of landslide risk assessment for Ukrainian regions.

Thus, numerous case studies and results of profound research on landslide issues in the regional context are represented by prof. G. Rudko [10], taking into consideration the geomorphological and climatic features of the territories.

There are lots of classifications of technogenic landslides developed on the basis of definitions of stable slope parameters at open pits [11]. Though, in terms of natural slopes, some of them are unacceptable due to the lack of ecological component of the landslide risk level.

Nevertheless, modern methods and approaches consider the slopes of open pit mines as the complex geotechnical structures having natural geological and geo-mechanical properties [12]. However, the represented methodology does not take into account the hydrogeological characteristics of the rock mass, which affect significantly their strength.

Numerous papers provide slope stability estimations using probabilistic approaches [13], [14]. The disadvantage of these methods is in the limited application of the known rock breaking criteria, which raises doubts about the reliability of the results.

To control the landslide risks for slopes in terms of large open pits, ground-based radars are used; that provides high accuracy in studying slope stability in real time [15], [16]. However, the use of geodetic radar does not provide a full picture of the deformation processes occurring within the rock mass at the moment of collapse.

To have complete evaluation of the slope stability, it is necessary to take into consideration the available cracks or other discontinuities within the medium [17] as well as the groundwater level and moisture saturation of the rock mass, which affects significantly the stability factor [18]. These are the key factors associated with the climate change, precipitation [3], and other natural factors, having considerable influence on the intensification of natural landslides.

Numerous publications deal with critical review of landslide classification systems to identify their limitations as well as their relevant criteria for classifying loess-slope failures [19]. In addition, the application of digital satellite data looks as the most promising trend for deep investigation, forecasting, and classification of landslides at a regional level [20].

The abovementioned analysis of the research regarding the landslide risks indicates the relevance of a landslide problem both in the regional context and globally. The influence of moisture saturation and soil watering due to excessive atmospheric precipitation acts as a trigger factor for landslide hazards. Taking into consideration the global climate changes, landslide forecasting and landslide risk classification are of great importance for the applied research.

\section{Formulation of the objectives and tasks}

The objective of the paper is to summarize and formalize the estimates of landslide levels based on the proposed classification of relevant environmental or man-made risks within both Ukrainian regions and local territories, including a gully-ravine network and man-made slopes in terms of geotechnical objects that represent certain environmental or man-made risks.

The available methods for assessing the landslide-risk levels of natural and man-made slopes do not provide reliable forecasting of the moment of landslide occurrence, ex- 
tent, and consequences; that is an obstacle to the implementation of preventive measures. Therefore, the scientific task is in practical forecasting of landslide risk levels for natural and technogenic slopes and estimating their possible consequences on the basis of classification of their ecological or technogenic hazard for certain changes in geoclimatic conditions.

To achieve the objective, the following tasks are set:

- to carry out zonal and statistical analysis of the orographic data for the regions of Ukraine and calculate the integral coefficients for landslide risk assessment depending on the precipitation amount and relief;

- to plot a geoclimatic model for landslide forecasting at regional and local levels;

- to substantiate the classification of landslide risks in terms of regions depending on annual precipitation and relief coefficients;

- to develop a scale of levels for "landslide risk - stability" of natural and man-made slopes according to the geomechanical criterion.

\section{Materials and methods}

Materials of the paper are based on the analysis of information sources regarding state-of-the-art research on the issues of landslide assessment at both regional and local levels.

To achieve the objectives, the following methodological approach was applied: methods of comprehensive stability evaluation for natural and man-made slopes with the consideration of their geometry, watering, geo-climatic conditions, and technogenic impacts; methods of geomechanical assessment, environmental evaluation, and forecasting landslide risks in terms of natural geosystems and man-made slopes based on the safety factor.

The research methodology combines the application of two approaches to determine the levels of landslide risks. The first approach is based on the zonal and statistical analysis of the orographic data for each region of Ukraine with calculations of the integrated terrain coefficients and plotting a geoclimatic model of landslide risks depending on the atmospheric precipitation. The second approach is based on the stability assessment of natural and man-made slopes, taking into consideration physical and mechanical properties of the rock mass and shear deformations.

To solve the specified tasks, the sequence for determining the landslide risk levels of both within the regions of Ukraine and within the local areas of the ravine-gully network, depending on the precipitation rate and terrain, is considered. Further, the classification of landslide risks at the regional and local levels as well as the relevant scale of landslide risks for natural and man-made slopes are substantiated according to the geomechanical criterion of stability. Practical aspects for application of the proposed classifications are studied.

\section{Results and discussion}

The achievements of the authors can be divided into two parts. The first one is based on the analysis of statistical data for the Ukrainian regions concerning the dependence of the number of landslides on the precipitation amounts in some regions taking into account the terrain features. As a result, a mathematical geoclimatic model of landslide risks was constructed, making it possible to forecast the landslide hazard at a regional level.
In particular, the model was the basis of the expression for determining parameters of the factors critical for the occurrence of a single landslide in terms of the gully-ravine network. Results of the second part are based on the laboratory studies to determine the strength characteristics of rocks and assessment of slope stability at open pits taking into account geological and hydrogeological characteristics of the rock mass. These results are significant for forecasting the levels of landslide risks for natural and man-made slopes. The obtained reliable estimates for landslide risk levels will help solve practical problems related to predicting the effects of landslides and controlling their prevention at regional and local levels.

To solve the specified task, the classification of landslide risk levels in Ukrainian regions and local territories of the gully-ravine network was considered, depending on the precipitation intensity and terrain features. Then, the definition and classification of the landslide levels for local natural and man-made slopes were analyzed, basing on the geomechanical slope stability.

The mathematical model of the dependence of the number of landslides upon the precipitation intensity and terrain features in certain regions is based on deep understanding of the landslide formation tendencies [21]. There were two main factors determining the landslide risk - terrain features and precipitation amount in certain regions. They were taken as a key concept of the model, in which the number of landslides is more in terms of those territories where the terrain is more rugged and the soil is moistened by increasing amount of precipitation. Therefore, the number of displacements, as the value of the mathematical model result, is directly proportional to the two input factors - relief and precipitation.

When developing the model, it is taken into account that the relief factor is relatively constant; thus, it is advisable for the model to take the coefficient into account. Atmospheric precipitation is changing dynamically, so this factor is selected as the input variable of the model.

Taking this approach into consideration, the values of the relief coefficients for each region of Ukraine were obtained initially by zonal and statistical analysis of the mapping data. Thus, on the basis of the averaged values of three relief components, the integral relief coefficients $\left(K_{i n t}\right)$ for each region are calculated using the formula:

$$
K_{\text {int }}=K_{\text {alt }} \cdot K_{\text {dens }} \cdot K_{\text {depth }},
$$

where:

$K_{a l t}-$ the altitude coefficient;

$K_{\text {dens }}-$ the relief density coefficient;

$K_{\text {depth }}-$ the relief depth coefficient, dimensionless.

The input data to calculate the abovementioned coefficients were obtained from cartographic materials taken from the geoecological web resource [22]. The averaged values of the relief coefficients were calculated for landslide occurrence in all the selected regions of Ukraine according to zonal and statistical analysis of geomorphological data.

The set of statistical data on the number of landslides in Ukraine per $1000 \mathrm{~km}^{2}\left(N_{l s}\right)$ was converted to the normalized values in terms of relief coefficient $N_{l s} / K_{\text {int }}$. Then a regression dependence of these values on annual precipitation $W(\mathrm{~mm})$ in certain Ukrainian regions was obtained according to meteorological statistics. 
As a result, a highly reliable linear regression equation is obtained:

$$
\frac{N_{l s}}{K_{\text {int }}}=0.011 \cdot W ; \quad R^{2}=0.9738 .
$$

Finally, the regional model of landslide risks, which estimates the number of landslides from the amount of precipitation, taking into account the relief coefficient, is represented by the equation:

$$
N_{l s}=0.011 \cdot K_{\text {int }} \cdot W \text {. }
$$

The highest reliability of this mathematical model is ensured in the range of precipitation from 350 to $1400 \mathrm{~mm} / \mathrm{year}$, and in terms of the values of integral relief coefficient from 3 to 11 . However, since the straight regression line originates from 0 point, the model can be considered reliable for the precipitations less than 350 and more than $1400 \mathrm{~mm} /$ year. Thus, extrapolation of the landslide number is possible.

Equation (3) characterizes the number of landslides per $1000 \mathrm{~km}^{2}$ of the area in a particular region with the corresponding annual precipitation amount. In addition, the number of landslides attributable to a precipitaion unit in the region with a particular relief is a constant value. That was the reason for determining the landslide potential in the regions of Ukraine (Table 1) and creating an appropriate classification, which is implemented in practice in the form of a landslide map (Fig. 1).

Table 1. Results of determining the potential landslide risks in the regions of Ukraine

\begin{tabular}{lccc}
\hline $\begin{array}{c}\text { Name of the } \\
\text { administrative } \\
\text { area (region) }\end{array}$ & $\begin{array}{c}\text { Precipitation } \\
\text { within the } \\
\text { regions, } \\
\text { mm/year* }\end{array}$ & $\begin{array}{c}\text { Integral } \\
\text { coefficient } \\
\text { of the relief } \\
\text { influence, } \\
\text { dimensionless }\end{array}$ & $\begin{array}{c}\text { Regional potential } \\
\text { landslide risks } \\
\text { in terms of precip- } \\
\text { tation, landslides } \\
\text { per 1000 km }{ }^{2}\end{array}$ \\
\hline AR Crimea & 753.75 & $K_{\text {int }}$ & $\left(N_{l s} / W=0.011 K_{\text {int }}\right)$ \\
Vinnytsia & 673.75 & 6.26 & 51.90 \\
Dnipropetrovsk & 558.50 & 4.13 & 49.07 \\
Donetsk & 538.50 & 5.02 & 25.35 \\
Zakarpattia & 1301.25 & 9.28 & 29.76 \\
Ivano-Frankivsk & 1032.25 & 9.75 & 132.88 \\
Kyiv & 609.25 & 4.15 & 110.73 \\
Luhansk & 494.50 & 5.61 & 27.80 \\
Lviv & 840.25 & 8.19 & 30.52 \\
Mykolayiv & 613.50 & 3.87 & 75.71 \\
Odesa & 600.25 & 4.19 & 26.12 \\
Poltava & 595.25 & 3.76 & 27.68 \\
Sumy & 568.00 & 4.43 & 24.65 \\
Kharkiv & 521.50 & 4.40 & 27.65 \\
Khmelnytsk & 661.00 & 6.80 & 25.23 \\
Cherkasy & 610.00 & 4.98 & 49.43 \\
Chernivtsi & 713.25 & 10.84 & 33.44 \\
\hline & & & 85.04 \\
\hline
\end{tabular}

Table 1 shows that the estimates of the number of annual landslides per $1000 \mathrm{~km}^{2}$ vary from a minimum value of 24.65 to a maximum value of 132.88 . Rather wide range of variations of the number of landslides in Ukrainian regions was devided into 5 ranges with a step multiple of 20 landslides, that characterizes the level of landslide risks, i.e.: < 20 - low landslide risk; 20-40 - moderate; 40-80 medium; 80-120 - high; > 120 - extraordinary.

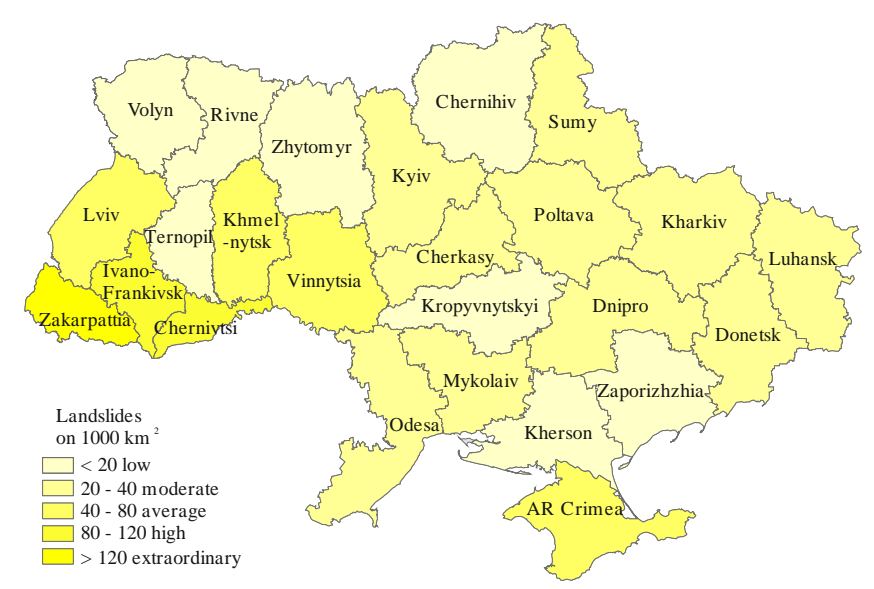

Figure 1. Map of the landslide risk forecast in the regions of Ukraine

Thus, it was possible to classify the potential landslide risks in Ukrainian regions by the estimated number of landslides, depending on the annual precipitation value, taking into account the relief and visualization on the map shown in Figure 1.

This map should be supplemented by the proposed classification of landslides represented in Table 2, which is proposed for landslide forecasting.

Table 2. Classification of landslide risks of regions as a factor of environmental safety due to the number of landslides depending on annual precipitation and relief coefficient

\begin{tabular}{ccc}
\hline $\begin{array}{c}\text { Level } \\
\text { of landslide risk }\end{array}$ & $\begin{array}{c}\text { Number of landslides } \\
\text { per } 1000 \mathrm{~km}^{2}\end{array}$ & $\begin{array}{c}\text { Class } \\
\text { of landslide risk }\end{array}$ \\
\hline Low & $<20$ & I \\
Moderate & $20-40$ & II \\
Medium & $40-80$ & III \\
High & $80-120$ & IV \\
Extraordinary & $>120$ & V \\
\hline
\end{tabular}

Equation (3) helps determine the precipitation amount that will cause at least one landslide per area $S, \mathrm{~km}^{2}$. The corresponding solution for this equation with respect to the precipitation intensity $W_{\mathrm{s}}$, causing a single landslide, is as follows:

$W_{s}=\frac{90.91}{K_{p s} \cdot S}, \mathrm{~mm}$

Obviously, at the local level, the critical precipitation for a single landslide in the gully-ravine network will vary depending on the specific area of a landslide-prone section and the corresponding relief index, as shown in Figure 2.

Equation (4) makes it possible to predict not only critical precipitation amount for single landslide in the gully-ravine network. On the one hand, the number-coefficient 90.91 in the numerator characterizes critical precipitation in $\mathrm{mm}$, which will cause a landslide within the landslide-prone area of $1 \mathrm{~km}^{2}$ with 1.0 relief coefficient. On the other hand, this value corresponds to the amount of water falling on the specified area, since it has $\mathrm{mm} \cdot \mathrm{km}^{2}$ dimension.

Finally, critical value of soil moisturing for the landslide effect at the landslide-prone section of the gully-ravine network with certain terrain can be estimated as follows:

$W_{s} S=\frac{90.91}{K_{p s}}, \mathrm{~mm} \cdot \mathrm{km}^{2}=\frac{90.91 \cdot 10^{3}}{K_{p s}}, \mathrm{~m}^{3}$. 


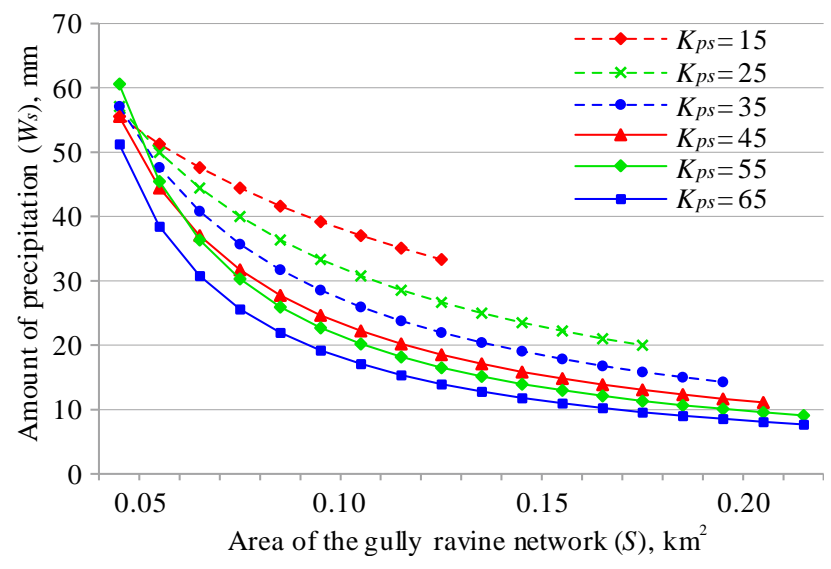

Figure 2. Critical amount of precipitation which will cause a single landslide within a certain section of the gully-ravine network for some values of integral relief coefficient $K_{p s}$

Equation (5) helps estimate the amount of moistured soil $V$ in $\mathrm{m}^{3}$ that is removed from the soil mass as a result of landslide. Divide the left and right parts of the Equation (5) by this value. We obtain the relative value of the critical soil moisture when the landslide occurs, which can be calculated in percent $W_{\mathrm{g}}, \%$ :

$$
W_{g}=\frac{V_{s} \cdot S \cdot 100}{V}=\frac{90.91 \cdot 10^{5}}{V \cdot K_{p s}}, \% \text {. }
$$

Thus, we obtain an equation for specifying the critical relative soil moisture:

$$
W_{g}=\frac{90.91 \cdot 10^{5}}{V \cdot K_{p s}}, \%,
$$

further we obtain the amount of the displaced soil volume $V$ :

$$
V=\frac{90.91 \cdot 10^{5}}{W_{g} \cdot K_{p s}}, \mathrm{~m}^{3} .
$$

Field studies of the soil moisture within the landslideprone slopes show that the values $W_{\mathrm{g}}$ vary within the range of $15-20 \%$ depending on the soil porosity and physical properties under natural conditions.

Therefore, substituting a certain moisture value for unstable soil, we determine the volume of the moistured soil displaced during a landslide.

Thus, in practice, to predict the displacement parameters for the local landslide, the integral coefficient of relief $K_{p s}$ must be determined.

The authors propose to define $K_{p s}$ as the product of the coefficients characterizing certain changes in the local terrain of a certain section of the gully-ravine network, i.e:

$$
K_{p s}=K_{a l t} \cdot K_{l s} \cdot K_{i s},
$$

where:

$K_{a l t}$ - the coefficient of difference in absolute altitudes along the gully-ravine network;

$K_{l s}$ - the coefficient of the most landslide-prone slope;

$K_{i s}$ - the coefficient of intersection for the most landslideprone slope.

These coefficients are calculated taking into account the schemes demonstrated in Figure 3 by the formulas:

$$
\begin{aligned}
& K_{\text {alt }}=\frac{1000 \cdot \Delta h}{L_{g e n}} ; \\
& K_{l s}=\frac{h_{s}}{l_{s}} ; \\
& K_{\text {is }}=\left(\frac{l_{\text {down }} \cdot l_{\text {up }}}{h_{s} \cdot l_{\text {down }}}\right),
\end{aligned}
$$

where:

$L_{g e n}$ - the general length of the gully, m;

$\Delta h$ - the difference in absolute altitudes along the gully, m; 1000 - the conversion factor, ppm;

$h_{s}$ - the absolute slope height, m;

$l_{s}-$ the slope length, m (Fig. 3a);

$l_{u p}, l_{\text {down }}-$ the width of the gully within the upper and lower relief respectively, $m$ (Fig. 3b).

(a)

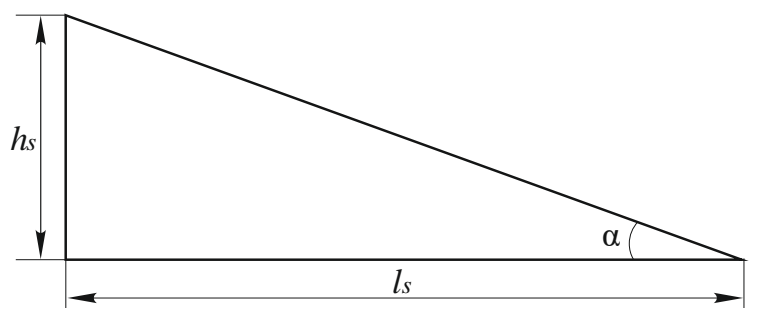

(b)

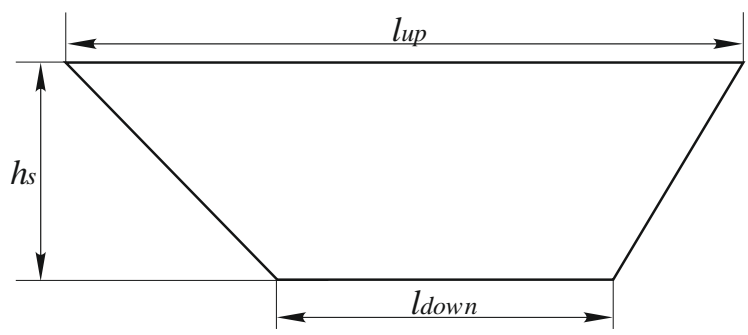

Figure 3. Explanatory diagrams for calculating a coefficient of the most landslide-prone slope $K_{l s}(a)$ and the coefficient of intersection Kis (b)

Thus, to predict the amount of precipitation $W_{s}$ that will cause a single landslide within a certain share of a gullyravine network with $S$ area estimated in $\mathrm{km}^{2}$, the integral coefficient of relief $K_{s}$ for this territory should be determined.

To illustrate the proposed model, we calculate the integral coefficient of relief $K_{p s}$ for landslide-prone gully Diivska (Diivka district, Dnipro). The gully geomorphology is caused by the joint influence of natural and man-made factors. As a result of the geomorphological survey of Diivska gully, the following baseline data were obtained to evaluate the landslide risks within the selected cross-section: $L_{\text {gen }}=1080 \mathrm{~m}$; $S=0.092 \mathrm{~km}^{2} ; \Delta h=22 \mathrm{~m} ; h_{s}=17 \mathrm{~m} ; l_{s}=4 \mathrm{~m} ; l_{\text {down }}=12 \mathrm{~m}$; $l_{u p}=42 \mathrm{~m}$.

The integral coefficient of terrain $K_{p s}$ and the amount of precipitation $W_{s}$ that cause a single landslide are determined as follows:

$$
\begin{aligned}
& K_{p s}=K_{a l t} \cdot K_{l s} \cdot K_{i s}=\frac{1000 \cdot \Delta h}{L_{g e n}} \cdot \frac{h_{s}}{l_{s}} \cdot \frac{l_{\text {down }}}{l_{\text {up }}} \cdot \frac{h_{s}}{l_{\text {down }}}= \\
& \frac{1000 \cdot 22}{1080} \cdot \frac{17}{4} \cdot \frac{12}{42} \cdot \frac{17}{12}=20.37 \cdot 4.25 \cdot 0.28 \cdot 1.42=35.04
\end{aligned}
$$


As a result, the intensity of precipitation critical value for a single landslide within the selected cross-section of the gully will be as follows: $W_{s}=90.91 / K_{p s}$, $S=90.91 / 35.04 \cdot 0.092=90.91 / 3.224=28.2 \mathrm{~mm}$.

Thus, $28.2 \mathrm{~mm}$ of precipitation during a very short period is a critical forecast for the occurrence of a single landslide within the most landslide-prone section of the gully. According to Equation (5), the water volume that will moisten critially the soil mass within the considered cross-section will be as follows:

$W_{s} \cdot S=28.2 \cdot 0.092 \cdot 10^{3}=2594 \mathrm{~m}^{3}$.

According to (6), the predicted volume of the soil displaced from the slope by the moisture value $W_{g}=17 \%$ during a landslide will be as follows:

$V=\frac{90.91 \cdot 10^{5}}{W_{g} \cdot K_{p s}}=\frac{90.91 \cdot 10^{5}}{17 \cdot 35.04}=15258 \mathrm{~m}^{3}$.

\subsection{Assessment of geomechanical stability and classification of landslide risk levels for local natural and technogenic slopes}

As is known, the criterion for evaluating the state of natural and man-made slopes is a stability factor $(S F)$, which represents the ratio of retention $F_{r}$ and landslide $F_{l}$ forces within the slope along the sliding surface, i.e.:

$S F=\frac{F_{r}}{F_{l}}$.

Three states of the slope section of the rock mass are possible: if $S F>1.0$, the slope is steady; if $S F=1.0$, that corresponds to the boundary state at the moment of slope collapse initiation, which goes into a state of collapse (landslide), if $S F<1.0$.

The $S F$ values for soft-rock slopes may vary widely, but for practical application of this criterion it is most appropriate to analyze the SF calculated values within the range of $[1.0 ; 2.0]$. In terms of complex effects of natural factors (including precipitation) and technogenic impacts, stresses within the slope increase resulting in the changes in stressstrain state of the slope mass. These changes are characterized by some transformations in the rock mass that can be controlled or observed. This was the basis for determining specific gradation of geomechanical condition of the slope and the corresponding levels for landslide risks or stability.

Thus, as a result of numerical simulation, it was found that in terms of the homogeneous slopes without displacements, significant deformations were practically nonavailable, if $S F \geq 1.5$ [23]. This state of soft rocks is characterized objectively as the most stable one; therefore, the landslide risk level is "low", which makes it possible to attribute this condition to the first class of the proposed scale. The increase in stresses within the slope $(1.2<S F \leq 1.5)$ results in certain deformations; the level of landslide is "moderate" that is classified as class II of landslide risks. Along with further decrease in strength properties of the soil or rock mass due to loads or changes in moisture saturation within the slope, the stress increases. There are separate zones of deformation, which helps consider the landslide level as "medium" and to attribute such a state to class III of landslide risk. Further development of geomechanical deformations $(1.0<S F \leq 1.1)$ results in cracks within the slope; that allows to consider the level of landslide risk as "increased" and distinguish class IV. The slope collapse condition, at which $S F=1.0$, is proposed to classify as the maximum level of landslide risk "critical" according to class V. Thus, it is possible to establish the gradation of the geomechanical state of natural or anthropogenic slopes in the form of a five-step scale of levels for "landslide risk-stability", which is represented in Figure 4.

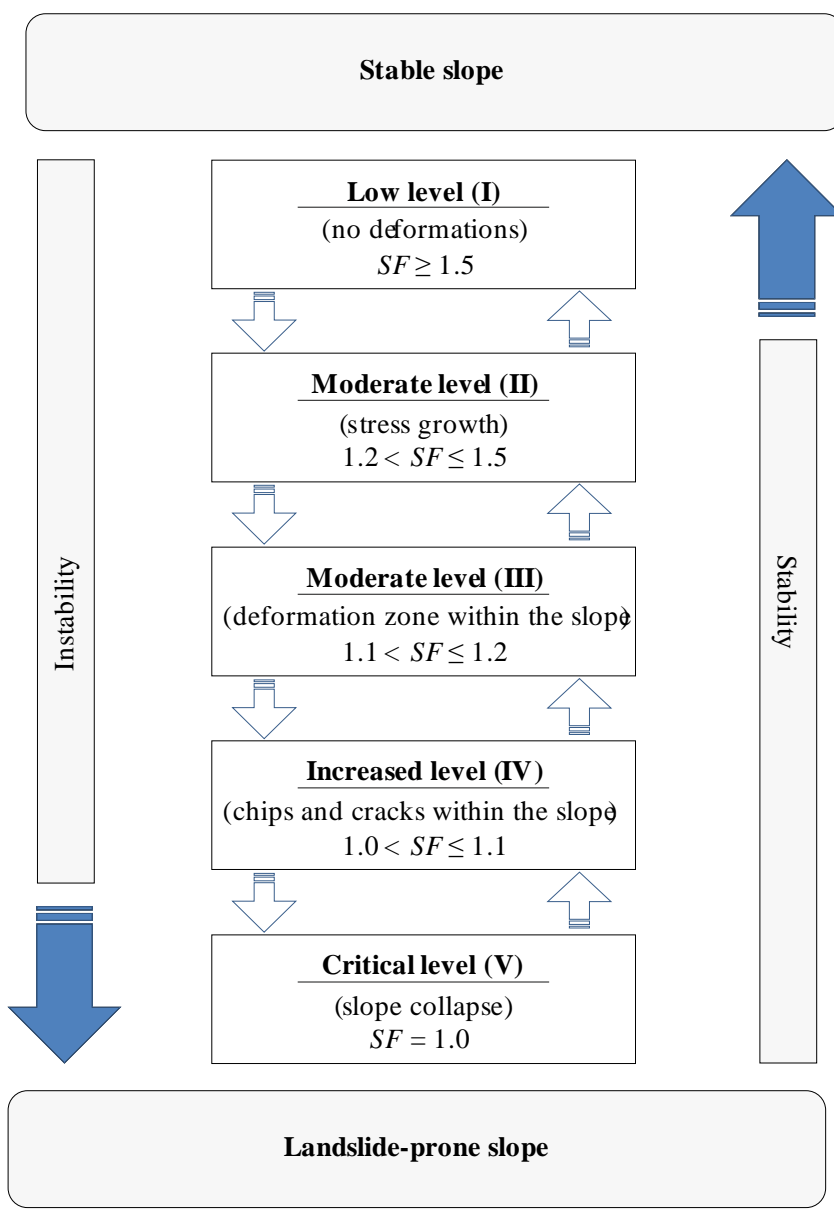

Figure 4. Five-step gradation of "landslide risk-stability" for local natural and man-made slopes according to the safety factor $(S F)$

It is noteworthy that the analysis of levels for slope stability proposed in [11] with respect to the open pit benches and overburden dumps of soft loamy rocks shows that the smallest values of $S F$ are within the range of 1.1-1.2. However, it should be considered that over time, such slopes tend to failure and shearing, and develop various landslides under the influence of external factors (mainly precipitation and overwatering). In addition, the determination of physical and mechanical properties of rocks under laboratory conditions has some drawbacks related to the variation of cohesion and friction angle values in real soils and rocks of slopes even within a selected engineering and geological component. Variations in strength properties and statistical heterogeneity of soils and loamy rocks can influence significantly the results of laboratory tests and, as a consequence, the calculation of SF values. Nevertheless, the proposed five-step scale of "landslide risk-stability" allows us to predict geomechanical condition of the natural and manmade slopes consisting of soft soils. 
As a result of the generalization, the authors propose an appropriate classification of landslides in terms of natural and man-made slopes, which is based on the $S F$ values (Table 3).

Table 3. Landslide risk levels of natural and man-made slopes according to $S F$ values

\begin{tabular}{|c|c|c|c|c|}
\hline $\begin{array}{l}\text { Land- } \\
\text { slide risk } \\
\text { levels }\end{array}$ & $\begin{array}{c}S F \text { value, } \\
\text { dimensionless }\end{array}$ & $\begin{array}{c}\text { Land- } \\
\text { slide } \\
\text { risk } \\
\text { class }\end{array}$ & $\begin{array}{l}\text { Risk } \\
\text { type }\end{array}$ & Note \\
\hline Low & $S F \geq 1.5$ & I & $\begin{array}{l}\text { Man- } \\
\text { made }\end{array}$ & $\begin{array}{l}\text { Used for man- } \\
\text { made slopes of }\end{array}$ \\
\hline Moderate & $1.2<S F \leq 1.5$ & II & $\begin{array}{l}\text { Man- } \\
\text { made }\end{array}$ & $\begin{array}{l}\text { solid and bulk } \\
\text { rocks }\end{array}$ \\
\hline Medium & $1.1<S F \leq 1.2$ & III & $\begin{array}{c}\text { Eco- } \\
\text { logical }\end{array}$ & $\begin{array}{l}\text { Characterizes } \\
\text { the environmen- }\end{array}$ \\
\hline Increased & $1.0<S F \leq 1.1$ & IV & $\begin{array}{l}\text { Eco- } \\
\text { logical }\end{array}$ & $\begin{array}{l}\text { tal hazard } \\
\text { caused by }\end{array}$ \\
\hline Critical & $S F=1.0$ & V & $\begin{array}{l}\text { Eco- } \\
\text { logical }\end{array}$ & $\begin{array}{l}\text { landslides due } \\
\text { to an emergency }\end{array}$ \\
\hline
\end{tabular}

The proposed classification makes it possible to determine the level of landslide risk in terms of natural and manmade slopes with the following forecasting of possible landslides with further development of effective engineering measures for land protection.

\section{Conclusions}

The geoclimatic model proposed by the authors makes it possible to determine the landslide risk in the regions of Ukraine by the estimated number of landslides depending on the characteristic annual precipitation values and relief indices. On the basis of this model, the classification with a fivestep scale of landslide risk ranking has been proposed: $<20$ landslides per year - low landslide risk; 20-40 - moderate; 40-80 - medium; 80-120 - high; > 120 - extraordinary.

On the basis of the proposed geoclimatic model, a partial model intended for practical determination of the critical precipitation that will cause at least one soil displacement within the territory of local gully-ravine network or manmade slope has been obtained. The partial model is proposed to be used for determining the coefficient of relief for a particular section of the gully of the specified area in the form of the product of the coefficient of difference of its absolute heights, the coefficient of a stope with the highest landslide risk, and the coefficient of intersection of the terrain with the highest landslide risk.

The critical precipitation and the degree of moisture that will cause the landslide as well as the volumes of landslide have been predicted. A possible landslide process in Diivska ravine in Dnipro has been considered as an example.

Alternative determination of the landslide levels for natural and man-made slopes has been proposed on the basis of the stress-strain state of soil or rock mass in terms of the safety factor $(S F)$ changes: no deformation $(S F \geq 1.5)$; increase in stresses $(1.2<S F \leq 1.5)$; formation of local deformation zones $(1.1<S F \leq 1.2)$; formation of cracks within the slope $(1.0<S F \leq 1.1)$; gradual slope collapse, landslide $(S F=1.0)$. The five-step grading scale of safety factors has made it possible to propose an appropriate classification of landslide risk levels and develop efficient anti-landslide engineering measures.

The obtained results have been integrated into a complex geomechanical, ecological, and climatic model of landslide risks for prediction and prevention of exogenous geological processes, accompanied by the landslides at regional and local levels, including man-made landslides.

\section{Acknowledgements}

The results represented in the paper have been obtained with no financial support of any grant or a scientific project. The team of authors expresses their gratitude to the reviewers for valuable recommendations that have been taken into account to improve significantly the quality of this paper.

\section{References}

[1] Yevdin, O.M., Kovalenko, V.V., \& Kropyvnytskyi, V.S. (2015). Natsionalna dopovid pro stan tekhnogennoi ta pryrodnoi bezpeky $v$ Ukraini u 2014 rotsi. Kyiv, Ukraina: Derzhavna sluzhba Ukrainy z nadzvychainykh sytuatsii.

[2] Bondar, O.I. (2016). Natsionalna dopovid pro stan navkolyshnoho pryrodnoho seredovyscha v Ukraini u 2015 rotsi. Kyiv, Ukraina: Ministerstvo zakhystu dovkillia ta pryrodnykh resursiv Ukrainy.

[3] Gariano, S.L., \& Guzzetti, F. (2016). Landslides in a changing climate. Earth-Science Reviews, (162), 227-252. https://doi.org/10.1016/j.earscirev.2016.08.011

[4] Petley, D. (2012). Global patterns of loss of life from land-slides. Geology, 40(10), 927-930. https://doi.org/10.1130/G33217.1

[5] Crozier, M.J. (2010). Deciphering the effect of climate change on landslide activity: A review. Geomorphology, (124), 260-267. https://doi.org/10.1016/j.geomorph.2010.04.009

[6] Seneviratne, S.I., Nicholls, N., Easterling, D., Goodess, C.M., Kanae, S., Kossin, J., Luo, Y., Marengo, J., McInnes, K., Rahimi, M., Reichstein, M., Sorteberg, A., Vera, C., \& Zhang, X. (2012). Changes in climate extremes and their im-pacts on the natural physical environment. In Managing the risks of extreme events and disasters to advance climate change adaptation (pp. 109-230). A Special report of working groups I and II of the Intergovernmental Panel on Climate Change (IPCC). Cambridge, United Kingdom: Cambridge University Press.

[7] Comegna, L., Picarelli, L., Bucchignani, E., \& Mercogliano, P. (2013). Potential effects of incoming climate changes on the behaviour of slow active landslides in clay. Landslides, 10(4), 373-391. https://doi.org/10.1007/s10346-012-0339-3

[8] Rianna, G., Zollo, A.L., Tommasi, P., Paciucci, M., Comegna, L., \& Mercogliano, P. (2014). Evaluation of the effects of climate changes on landslide activity of Orvieto clayey slope. Procedia Earth Planetary Science, (9), 54-63. https://doi.org/10.1016/j.proeps.2014.06.017

[9] Chang, S.-H., \& Chiang, K.-T. (2011). The potential impact of climate change on typhoontriggered landslides in Taiwan, 2010-2099. Geomorphology, (133), 143-151. https://doi.org/10.1016/j.geomorph.2010.12.028

[10] Rudko, G.I., \& Osiuk, V.A. (2012). Inzhenernaya geodinamika Ukrainy i Moldovy (opolznevye geosistemy). Bukrek: Znanie.

[11] Galperin, A.M. (2003). Geomechanics of open-cast mining. Moscow, Russian Federation: Publishing House of the Moscow State Mining University.

[12] Fleurisson, J-A. (2012). Slope design and implementation in open pit mines: Geological and geomechanical approach. Procedia Engineering, (46), 27-38. https://doi.org/10.1016/j.proeng.2012.09.442

[13] Hamedifar, H., Bea, R.G., Pestana-Nascimento, J.M., \& Roe, E.M (2014). Role of probabilistic methods in sustainable geotechnical slope stability analysis. Procedia Earth and Planetary Science, (9), 132-142. https://doi.org/10.1016/i.proeps.2014.06.009

[14] Luo, N., Bathurst, R.J., \& Javankhoshde, S. (2016). Probabilistic stability analysis of simple reinforced slopes by finite element method. Computers and Geotechnics, (77), 45-55. https://doi.org/10.1016/j.compgeo.2016.04.001

[15] Severin, J., Eberhardtb, E., Leonic, L., \& Fortind, S. (2014). Development and application of a pseudo-3D pit slope displacement map derived from ground-based radar. Engineering Geology, (181), 202-211. https://doi.org/10.1016/j.enggeo.2014.07.016

[16] Osasan, K.S., \& Stacey, T.R. (2014). Automatic prediction of time to failure of open pit mine slopes based on radar monitoring and inverse velocity method. International Journal of Mining Science and Technology, 24(2), 275-280. https://doi.org/10.1016/j.ijmst.2014.01.021

[17] Zhao, L-H., Cheng, X., Zhang, Y., Li, L., \& Li, De-J. (2016). Stability analysis of seismic slopes with cracks. Computers and Geotechnics, (77), 77-90. https://doi.org/10.1016/j.compgeo.2016.04.007 
[18] Lu, L., Wang, Z.J., Song, M.L., \& Arai, K. (2015). Stability analysis of slopes with ground water during earthquakes. Engineering Geology, (193), 288-296. https://doi.org/10.1016/j.enggeo.2015.05.001

[19] Li, Y., \& Mo, P. (2019). A unified landslide classification system for loess slopes: A critical review. Geomorphology, 340(1), 67-83. https://doi.org/10.1016/j.geomorph.2019.04.020

[20] Kalia, A. (2018). Classification of landslide activity on a regional scale using persistent scatterer interferometry at the Moselle Valley (Germany). Remote Sensing, 10(12), 1880. https://doi.org/10.3390/rs10121880
[21] Kovrov, O.S., Kolesnik, V.Ye., \& Buchavyi, Yu.V. (2018). Evaluation of the influence of climatic and geomorphological factors on landslides development. Environmental safety and natural resources, 1-2(25), 121-132. https://doi.org/10.32347/2411-4049.2018.1.52-63

[22] Grachev, A. (2010). Orohrafichna karta Ukrainy. Retrieved from http://geomap.land.kiev.ua/orographic.html

[23] Sdvizhkova, Ye.A., Kovrov, A.S., \& Kiriak, K.K. (2014). Geomekhanicheskaya ocenka ustoichivosti opolznevogo sklona metodom konechnykh elementov. Scientific Bulletin of the National Mining University, (2), 86-92.

\section{Розробка класифікації зсувонебезпеки природних схилів} і штучних укосів за ступенем зволоження та деформації грунтів

\section{О. Ковров, В. Колесник, Ю. Бучавий}

Мета. Узагальнення та формалізація оцінки рівнів зсувонебезпеки на основі запропонованої класифікації відповідної екологічної або техногенної небезпеки як регіонів України, так і локальних територій, включаючи яружно-балочну мережу та штучні укоси техногенних об’єктів, які являють певну екологічну або техногенну небезпеку.

Методика. Для досягнення мети застосовано наступні методологічні підходи: аналіз першоджерел стосовно оцінки та прогнозу зсувів на регіональному та локальному рівнях, зонально-статистичний аналіз орографічних даних для кожного регіону України 3 розрахунками відповідних інтегральних коефіцієнтів рельєфу, методи комплексної оцінки природних і техногенних схилів 3 урахуванням їх геометрії, водонасичення, геокліматичних умов і техногенних впливів, методи геомеханічної оцінки, екологічної оцінки та прогнозування небезпеки зсуву в природних геосистемах і техногенних укосах на основі коефіцієнта запасу стійкості, наукове узагальнення зсувонебезпеки на основі розроблених авторами математичних моделей і запропонованих критеріїв стосовно зволоження та деформації масиву грунтів природних схилів і штучних укосів.

Результати. Обгрунтовано 5-рівневу оціночну шкалу зсувонебезпечності природних схилів і техногенних укосів для управління їх стійкістю. Визначена шкала зсувонебезпечності дозволяє достовірно прогнозувати геомеханічний стан масиву гірських порід залежно від значень коефіцієнта запасу стійкості схилу в мінливих геокліматичних умовах та обгрунтовувати ефективні заходи інженерного захисту від зсувів. Запропоновано класифікацію зсувонебезпечності природних схилів та укосів за значенням коефіцієнтів запасу стійкості. Рекомендовано використовувати шкалу як для оцінки стійкості техногенних укосів суцільних і насипних порід, так і для прогнозу екологічної небезпеки від зсувів внаслідок надзвичайних ситуацій.

Наукова новизна. Доведено, що кількість зсувів, яка припадає на одиницю опадів у регіоні з певним рельєфом, є постійною величиною. Отримано залежності для визначення критичної кількості опадів, що спричинить одиничний зсув у яружно-балочній мережі залежно від конкретної площі зсувонебезпечної ділянки та характеру рельєфу.

Практична значимість. Обгрунтовано п'ятиступінчасту класифікацію рівнів зсувонебезпеки природних схилів і штучних укосів залежно від річних опадів та коефіцієнта рельєфу місцевості, що дозволяє прогнозувати зсуви й визначати рівень екологічної та техногенної небезпеки від зсувів.

Ключові слова: зсув, зсувонебезпека, природні схили, техногенні укоси, класифікація рівнів зсувонебезпеки

\section{Разработка классификации оползнеопасности естественных склонов и искусственных откосов по степени увлажнения и деформации грунтов}

\section{А. Ковров, В. Колесник, Ю. Бучавый}

Цель. Обобщение и формализация оценки уровней оползнеопасности на основе предложенной классификации соответствующей экологической или техногенной опасности как регионов Украины, так и локальных территорий, включая овражно-балочную сеть и искусственные откосы техногенных объектов, представляющих определенную экологическую или техногенную опасность.

Методика. Для достижения цели применены следующие методологические подходы: анализ первоисточников по оценке и прогнозу оползней на региональном и локальном уровнях, зонально-статистический анализ орографических данных для каждого региона Украины по расчетам соответствующих интегральных коэффициентов рельефа, методы комплексной оценки природных и техногенных склонов с учетом их геометрии, водонасыщения, геоклиматических условий и техногенных воздействий, методы геомеханической оценки, экологической оценки и прогнозирования опасности оползней в природных геосистемах и техногенных откосах на основе коэффициента запаса устойчивости, научное обобщение оползнеопасности на основе разработанных авторами математических моделей и предложенных критериев относительно увлажнения и деформации массива почв естественных склонов и искусственных откосов.

Результаты. Обоснована 5-уровневая оценочная шкала оползнеопасности природных склонов и техногенных откосов для управления их устойчивостью. Разработанная шкала оползнеопасности позволяет достоверно прогнозировать геомеханическое состояние массива горных пород в зависимости от значений коэффициента запаса устойчивости склона в меняющихся геоклиматических условиях и обосновывать эффективные меры инженерной защиты от оползней. Предложена классификация оползнеопасности природных склонов и откосов по значению коэффициентов запаса устойчивости. Рекомендуется использовать шкалу как для оценки устойчивости техногенных откосов сплошных и насыпных пород, так и для прогноза экологической опасности от оползней в результате чрезвычайных ситуаций.

Научная новизна. Доказано, что количество оползней, приходящееся на единицу осадков в регионе с определенным рельефом, является постоянной величиной. Получены зависимости для определения критического количества осадков, что повлечет единичный оползень в овражно-балочной сети в зависимости от конкретной площади оползнеопасного участка и характера рельефа.

Практическая значимость. Обоснована пятиступенчатая классификация уровней оползнеопасности естественных склонов и искусственных откосов в зависимости от годовых осадков и коэффициента рельефа местности, позволяет прогнозировать оползни и определять уровень экологической и техногенной опасности от оползней.

Ключевые слова: оползень, оползнеопасность, природные склоны, техногенные откосы, классификация уровней оползнеопасности

\section{Article info}

Received: 12 March 2020

Accepted: 20 November 2020

Available online: 7 December 2020 